welfare of a society through genetic improvement of crops, while at the same time improving breeding methods and advancing knowledge in attaining that goal. This perspective needs to be imparted to graduate students, administrators of land-grant institutions, and funding agencies because of the continued erosion of plant breeding programs. It is imperative for the future well-being of humanity that we continue to train plant breeders to meet the stated goal.

In some cases, sufficiently high levels of resistance to some pathogens of many crops have not been secured through classical breeding. In this category are physiological resistance to the fungus Sclerotinia sclerotiorum [(Lib.) de Bary], some gemini viruses, and bacterial pathogens. Molecular approaches alone, or in combination with classical breeding, may be the most useful approach to attain a desired resistance level. Breeding for virus resistance has proved to be long, difficult, and costly in some crops. Transgenic plants with high levels of resistance to some virus diseases have been developed in recent years through insertion of a gene controlling the virus coat protein into a host genome (see review by R. Grumet). This goal can be achieved in a short time in comparison with traditional breeding procedures. Grumet also discusses other strategies to develop transgenic virus-resistant plants.

Classical breeding procedures have not been successful in introducing high levels of resistance to some bacterial pathogens into acceptable crop lines or varieties. The recent introduction of foreign genes that control specific peptides with antibacterial properties from nonplant sources into desired susceptible horticultural varieties may provide high levels of resistance to a broad spectrum of bacterial pathogens (see review by A.K. Kuehnle). This approach is particularly valuable where it is desired to maintain the original genotype of the variety, except for the introduced foreign gene, and where the classical backcross method is difficult to use or cannot be used to constitute the genotype due to incompatibility, as in apple (Malus domestica Borkh.) (see review by S.M. Mehlenbacher).

If an introduced foreign gene does not provide a high enough level of disease resistance, it may be useful to determine if enhanced levels of resistance can be obtained by combining the foreign gene with genes for moderate resistance that accumulated in lines through classical breeding procedures. The stability of expression of the foreign gene and its expression in the desired plant parts also must be determined.

Gene pyramiding to combine resistance to various races of a pathogen to enhance durability of resistance and to reduce genetic vulnerability to the pathogen has been difficult using classical procedures. The difficulty resides in the repeated testing needed with strains to identify the required genes and in the problem of epistasis of genes, which requires test crosses to detect the hypostatic gene. The use of RAPD molecular markers to "tag" genes for resistance to various strains of rust and bean common mosaic virus is now being used by J.D. Kelly (see review paper) to pyramid genes for resistance to strains of those pathogens in common beans (Phaseolus vulgaris L.). Selection for resistance to the above pathogens using molecular markers in the absence of the disease likely also will be practicable.

Breeding for resistance to a pathogen whose inheritance is complex and of low heritability may be difficult using classical breeding procedures. Molecular-marker-assisted selection (MAS) may be more efficient than phenotypic selection under certain conditions. This procedure probably will require detection of quantitative trait loci (QTLs) that would explain a major portion of the variability for the trait. If the heritability of the trait can be increased through improved screening procedures and if appropriate population sizes are used, then QTL detection will be improved.

Mehlenbacher provides a broad overview of current developments in breeding small fruit and tree fruit using classical methods, molecular mapping, MAS, and transformation procedures. He also discusses the role of classical and molecular approaches in breeding crop plants and the current status of plant breeding in public institutions in the United States.

The colloquium concluded with a presentation by Eskridge (see review paper) dealing with the use of nonparametric statistical methods, because data obtained from experiments dealing with disease reactions do not adhere to the standard assumptions underlying the classical analysis of variance. Examples are provided of the value of using nonparametric procedures vs. parametric methods. Detecting more disease-resistant lines to various pathogens in diverse situations is possible using nonparametric methods (Eskridge).

This colloquium is broad in scope and contains subject matter of interest to all breeders of horticultural plants. The information should be especially useful to those involved in teaching graduate courses in plant breeding and for graduate students entering the profession, because it contains "state of the art" information on breeding for disease resistance.

\title{
Genetic Engineering for Crop Virus Resistance
}

\author{
Rebecca Grumet \\ Department of Horticulture, Michigan State University, East Lansing, MI 48824
}

The advances of the past decade in plant transformation and the genetic engineering of virus resistance have provided some of the most dramatic recent developments in our ability to increase genetic resistance to plant diseases. In fact, engineered virus resistance was one of the first successful demonstrations of the introduction of any agriculturally useful trait into plants (Gasser and Fraley, 1989). Engineered plant virus resistance remains a highly active area of research and development by public institutions and industry.

One of the major contributing factors to the early, rapid, and widespread development of genetically engineered virus resistance is the source of genes that are used. As will be discussed further, with the exception of some recent experiments with animal-based systems (antibodies, Tavladoraki et al., 1993; interferon-related proteins, Truve et al., 1993), in every case the genes that were used came from the

Received for publication 20 Oct. 1994. Accepted for publication 16 Nov. 1994. I thank Jim Kelly and Robert Herner for their helpful reviews of the manuscript. The cost of publishing this paper was defrayed in part by the payment of page charges. Under postal regulations, this paper therefore must be hereby marked advertisement solely to indicate this fact. genome of the virus (Table 1). To my knowledge, there are no examples at this time where engineered virus resistance was achieved using a gene from the host. The practical significance of our ability to use viral genes is that they generally are easy to clone. The use of such genes, however, is only possible with the concurrent development of appropriate plant transformation technologies.

In the past 8 years, there have been more than 70 reports of genetically engineered virus resistance. The number of plant viruses for which engineered resistance has been achieved, the number of plant species into which these genes have been introduced, and the types of genes that have been used are increasing rapidly. This review focuses on the progress that has been made toward the development of virus-resistant crops and will emphasize applied aspects of the work rather than discussions of mechanism. I will use various examples, including those from my laboratory group, to illustrate different aspects of the engineered resistance. Recent reviews related to this topic include those by Beachy et al. (1990), Fitchen and Beachy (1993), Gandani et al. (1990), Grumet (1990, 1994), Hull and Davies (1992), Nelson et al. (1990), Scholtof et al. (1993), and Wilson (1993).

To develop an engineered crop with an agriculturally useful trait, 
Table 1. Types of genes that have been used to genetically engineer virus resistance in plants.

\begin{tabular}{|c|c|c|c|}
\hline Type of gene & Source & First example & $\begin{array}{c}\text { No. } \\
\text { examples }\end{array}$ \\
\hline Coat protein & Virus & 1986-Powell-Abel et al. & 44 \\
\hline Satellite & $\begin{array}{l}\text { Virus- } \\
\text { associated }\end{array}$ & $\begin{array}{l}\text { 1987—Gerlach et al. } \\
\text { 1987_Harrison et al. }\end{array}$ & 6 \\
\hline $\begin{array}{l}\text { Antisense, sense } \\
\text { defective RNAs }\end{array}$ & Virus & $\begin{array}{l}\text { 1988-Cuozzo et al. } \\
\text { 1988-Hemenway et al. }\end{array}$ & 15 \\
\hline $\begin{array}{l}\text { Replicase } \\
\text { Defective-interfering }\end{array}$ & Virus & 1990_Golemboski et al. & 8 \\
\hline sequences & Virus & 1990-Stanley et al. & 3 \\
\hline Movement protein & Virus & 1993-Malysheko et al. & 1 \\
\hline Protease & Virus & 1993_Vardi et al. & 1 \\
\hline Antibody & Animal & 1993-Tavladoraki et al. & 1 \\
\hline $\begin{array}{l}\text { Interferon-related } \\
\text { protein }\end{array}$ & Animal & 1993-Truve et al. & 1 \\
\hline
\end{tabular}

two components must come together: a suitable transformation system and useful genes. Although transformation per se is not within the focus of this discussion, and I will not describe the various methods, I do not want to ignore its importance, for it can be a limiting factor. For each crop of interest, it is necessary to develop the appropriate regeneration and transformation technologies; depending on the species in question, this can be very challenging. In fact, until 1991, all published examples of genetically engineered virus resistance were in either tobacco (Nicotiana tabacum L.) or related Nicotiana species, or tomato, or potato; i.e., Solanaceous species that are comparatively easy to transform. Progress is being made, however, as more crops receive effort. In the past few years, examples have been published for other diverse crops (Fang and Grumet, 1993; Fitch et al., 1992; Gonsalves et al., 1992, 1994; Hayakawa et al., 1992; Hill et al., 1991; Murray et al., 1993; Zaccomer et al., 1993) (Table 2).

The second critical component is the gene to be transferred. As noted, with regard to engineered virus resistance, in almost every case the source of resistance genes has been the virus itself. The theoretical basis for the use of virus-derived genes as a source of resistance genes has been termed pathogen-derived resistance (Sanford and Johnston, 1985). The concept of pathogen-derived resistance states that it should be possible to disrupt the normal life cycle of a pathogen by causing the host to express a pathogen gene at the wrong time, in the wrong amount, or in a counterfunctional form. Either native or altered viralderived genes might be used to interfere with various stages in the viral life cycle, such as uncoating, translation, replication, cell-to-cell or long-distance movement, or vector-mediated transmission.

Table 2. Plant species that have been genetically engineered for virus resistance.

\begin{tabular}{|c|c|c|}
\hline Species & $\begin{array}{l}\text { No. published } \\
\text { examples }\end{array}$ & Viruses $^{2}$ \\
\hline $\begin{array}{l}\text { Tobacco } \\
\text { (Nicotiana tabacum L.) }\end{array}$ & 37 & $\begin{array}{l}\text { AlMV, ArMV, CMV } \\
\text { PVX, PVY, TEV } \\
\text { TGMV, TMV, TRV } \\
\text { TSV, TSWV }\end{array}$ \\
\hline $\begin{array}{l}\text { Other Nicotiana spp. } \\
(\text { N. debneyii, N. benthamiana, } \\
\quad \text { N. clevelandii) }\end{array}$ & 12 & $\begin{array}{l}\text { ACMV, BYMV, CyMV } \\
\text { CyRSV, BCTV, PEBV } \\
\text { PPV, PVS, WMV }\end{array}$ \\
\hline $\begin{array}{l}\text { Potato (Solanum tuberusom L.) } \\
\text { Tomato }\end{array}$ & 10 & PLRV, PVY \\
\hline (Lycopersicon esculentum L.) & 5 & AlMV, CMV, TMV, TYLCV \\
\hline Cucumber (Cucumis sativus L.) & 1 & CMV \\
\hline Melon (Cucumis melo L.) & 2 & CMV, ZYMV \\
\hline Alfalfa (Medicago sativa $\mathrm{L})$. & 1 & AlMV \\
\hline Papaya (Carica papaya L.) & 1 & PRSV \\
\hline Corn (Zea mays L.) & 1 & MDMV \\
\hline Rice (Oryza sativa L.) & 1 & RSV \\
\hline Rapeseed (Brassica napus L.) & 1 & TYMV \\
\hline
\end{tabular}

${ }^{2}$ See Tables 3-6 for references and complete virus names.
The use of pathogen-derived resistance can be contrasted with conventional breeding, which, of necessity, relies on host genes that can be transferred between interfertile relatives. Clearly, great progress has been made in developing virus-resistant cultivars for a range of crops and viruses using conventional methods (e.g., Kyle, 1993). Undoubtedly, conventional breeding will continue to play a dominant role in the future production of virus-resistant crops. There can, however, be limitations to conventional breeding approaches. The desired resistance is not always available in a closely related, interfertile relative; the genes for resistance may be tightly linked to undesirable traits; or the resistance may be multigenic and difficult to transfer (Knott and Dvorak, 1976; Wenzel, 1985).

From a genetic engineering standpoint, the use of viral genes has several advantages. Viruses have tiny genomes and short life cycles, thereby making it easy to identify, isolate, and clone a given viral gene. In contrast, most plant species have large genomes, large amounts of repetitive DNA, and, despite active, ongoing efforts, are not well mapped. Furthermore, in the great majority of cases, the underlying mechanism of resistance is not known; thus, there is no tag by which to identify and isolate the resistance genes. All of these features make cloning a host-encoded resistance gene difficult.

Even when using virus-encoded genes, several steps are involved in developing a transgenic, virus-resistant plant. First, the virus must be purified and the viral RNA or DNA isolated. For an RNA virus (note that $>90 \%$ of plant viruses have RNA genomes; Zaitlin and Hull, 1987), the isolated viral RNA is used as a template for reverse transcriptase to produce a cDNA copy of the viral genome. The viral gene(s) must then be identified, sequenced, and engineered into an expression vector that will facilitate expression in plants. These steps include adding transcriptional and, possibly, translational information; if transformation is to be done using Agrobacterium, Ti borders also will be added. Transformation methods most commonly used include Agrobacterium-mediated transformation or particle bombardment. Since only a fraction of a percent of the exposed cells will become transformed, the transformation plasmid generally also includes a selectable marker gene for antibiotic resistance, thereby enabling only those cells that express the introduced gene to grow, divide, and regenerate on medium containing the appropriate antibiotic.

Successful transformation is verified by testing for incorporation of the introduced gene into the host chromosome by Southern blot, polymerase chain reaction analysis, or both, and by verification of transfer to the next generation. Expression of the gene is verified by analyzing for production of the expected mRNA (northern blot) and protein [western blot or enzyme-linked immunosorbent assay (ELISA)]. As with any introduced gene, not all transgenic plants express a given viral gene construct to the same extent. This variation can have importance when selecting lines that exhibit the greatest resistance, but note that there is not always a direct correlation between levels of gene expression and resistance, as will be discussed later.

\section{EXAMPLES OF ENGINEERED RESISTANCE TO VIRUSES}

\section{Coat protein-mediated resistance}

The first example of genetically engineered plant virus resistance was published in 1986 (Powell-Abel et al., 1986). The coat protein (CP) gene from tobacco mosaic virus (TMV) was inserted into tobacco and the resultant transgenic plants, which constitutively produced viral coat protein, were more resistant to infection by TMV than were control, nontransgenic plants. The coat protein-mediated approach to engineer resistance has proved to be widely applicable to a range of viruses, including positive sense, negative sense, single-, and doublestranded RNA viruses, and at least one DNA virus (Table 3). The viruses differ in particle morphology, genome organization, and mode of transmission, and represent at least 13 different virus groups. Abbreviations of virus names will be used throughout the text; the full names are listed in Tables 3, 5, 6, and 7 .

The extent of protection conferred by the $\mathrm{CP}$ genes is variable, depending on the type of virus and the individual transgenic line. In general, following inoculation with the virus from which the $\mathrm{CP}$ gene 
Table 3. Genetically engineered plant virus resistance using viral coat protein genes.

\begin{tabular}{|c|c|c|c|c|}
\hline Virus group & Virus & Abbreviation & Host species & Reference \\
\hline \multirow[t]{4}{*}{ Alfalfa mosaic virus group } & Alfalfa mosaic virus & AlMV & Tobacco & Loesch-Fries et al., 1987 \\
\hline & & & Tobacco & van Dun et al., 1987 \\
\hline & & & Tobacco, tomato & Tumer et al., 1987 \\
\hline & & & Alfalfa & Hill et al., 1991 \\
\hline \multirow[t]{2}{*}{ Carlavirus } & Potato virus $\mathrm{S}$ & PVS & Nicotiana debneyii & Mackenzie and Tremaine, 1990 \\
\hline & & & Potato & Mackenzie et al., 1991 \\
\hline \multirow[t]{5}{*}{ Cucumovirus } & Cucumber mosaic virus & CMV & Tobacco & Cuozzo et al., 1988 \\
\hline & & & Tobacco & Quemada et al., 1991 \\
\hline & & & Tobacco & Nakajima et al., 1993 \\
\hline & & & Cucumber & Gonsalves et al., 1992 \\
\hline & & & Melon & Gonsalves et al., 1994 \\
\hline Geminivirus & Tomato yellow leaf curl virus & TYLCV & Tomato & Kunick et al., 1994 \\
\hline Ilarvirus & Tobacco streak virus & TSV & Tobacco & van Dun et al., 1988 \\
\hline \multirow[t]{3}{*}{ Luteovirus } & Potato leafroll virus & PLRV & Potato & Kawchuk et al., 1990 \\
\hline & & & Potato & van der Wilk et al., 1991 \\
\hline & & & Potato & Barker et al., 1992 \\
\hline \multirow[t]{2}{*}{ Nepovirus } & Arabis mosaic virus & ArMV & Tobacco & Bertiolo et al., 1992 \\
\hline & Grapevine chrome mosaic virus & GCMV & Tobacco $^{z}$ & Brault et al., 1993 \\
\hline \multirow{6}{*}{ Potexvirus } & Cymbidium mosaic virus & СуMV & N. benthamiana ${ }^{z}$ & Chia et al., 1992 \\
\hline & Potato virus $\mathrm{X}$ & PVX & Tobacco & Hemenway et al., 1988 \\
\hline & & & Potato & Hoekema et al., 1989 \\
\hline & & & Potato & Kaniewski et al., 1990 \\
\hline & & & Potato & Lawson et al., 1990 \\
\hline & & & Potato & Jongedijk et al., 1992 \\
\hline \multirow[t]{12}{*}{ Potyvirus } & Bean yellow mosaic virus & BYMV & N. benthamiana & Hammond and Kamo, 1993 \\
\hline & Lettuce mosaic virus & LMV & Tobacco $^{y}$ & Dinant et al., 1993 \\
\hline & Maize dwarf mosaic virus & MDMV & Corn & Murray et al., 1993 \\
\hline & Papaya ringspot virus & PRSV & Tobacco $^{y}$ & Ling et al., 1991 \\
\hline & & & Papaya & Fitch et al., 1992 \\
\hline & Plum pox virus & PPV & N. clevelandii & Regner et al., 1992 \\
\hline & Potato virus $\mathrm{Y}$ & PVY & Potato & Lawson et al., 1990 \\
\hline & & & Potato & Kaniewski et al., 1990 \\
\hline & Soybean mosaic virus & SMV & Tobacco $^{y}$ & Stark and Beachy, 1989 \\
\hline & Watermelon mosaic virus & WMV & N. benthamiana & Namba et al., 1992 \\
\hline & Zucchini yellow mosaic virus & ZYMV & N. benthamiana ${ }^{y}$ & Namba et al., 1992 \\
\hline & & & Melon, tobacco & Fang and Grumet, 1993 \\
\hline Tenuivirus & Rice stripe virus & RSV & Rice & Hayakawa et al., 1992 \\
\hline \multirow[t]{3}{*}{ Tobamovirus } & Tobacco mosaic virus & TMV & Tobacco & Powell-Abel et al., 1986 \\
\hline & & & Tomato & Nelson et al., 1988 \\
\hline & & & Tomato & Sanders et al., 1992 \\
\hline & Tobacco rattle virus & TRV & Tobacco & van Dun and Bol, 1988 \\
\hline \multirow[t]{3}{*}{ Tospovirus } & Tomato spotted wilt virus & TSWV & Tobacco & Gielen et al., 1991 \\
\hline & & & Tobacco & Pang et al., 1992 \\
\hline & & & Tobacco & MacKenzie and Ellis, 1992 \\
\hline
\end{tabular}

${ }^{2}$ The virus does not move systemically in this host.

yonly tested against heterologous viruses.

was derived, the inoculated leaves of the transgenic plants show 1) fewer viral lesions than do control plants; 2) systemic spread of infection is prevented, delayed, or reduced; or 3) both occur. In the majority of cases, virus accumulation is reduced or absent. For example, transgenic zucchini yellow mosaic virus (ZYMV) $\mathrm{CP}$ expressing melon plants did not show symptoms for up to 90 days after infection with ZYMV, nor were there detectable levels of virus accumulation (Fang and Grumet, 1993).

In some cases, the level of protection is related to the level of $\mathrm{CP}$ expression, e.g., alfalfa mosaic virus (AlMV) (Hill et al., 1991; Loesch-Fries et al., 1987), potato virus X (PVX) (Hemenway et al., 1988; Hoekema et al., 1989), rice stripe virus (RSV) (Hayakawa et al., 1992), and tomato yellow leaf curl virus (TYLCV) (Kunik et al., 1994). Comparisons among individual lines with different levels of expression, or between heterozygotes and homozygotes, indicate that higher levels of CP provide greater protection. Similarly, reduction of TMV CP levels by heat treatment resulted in reduced protection against TMV infection (Nejidat and Beachy, 1989). For other viruses, however, there is not necessarily a correlation between CP level and level of resistance, e.g., certain potyviruses (Lawson et al., 1990; Namba et al., 1992; Regner et al., 1992), luteoviruses (Kawchuk et al., 1990), and tospoviruses (Gielen et al., 1991; MacKenzie and Ellis, 1992; Pang et al., 1992). Protection against ZYMV also was not correlated with the level of protein expression (Fang and Grumet, 1993).

In many cases, it has been possible to overcome the CP-mediated resistance with increasing concentrations of viral inocula, e.g., TMV (Powell-Abel et al., 1986), AlMV (Tumer et al., 1987), tomato spotted wilt virus (MacKenzie and Ellis, 1992), soybean mosaic virus (Stark and Beachy, 1989), watermelon mosaic virus (WMV) (Namba et al., 1992), and ZYMV (Grumet et al., 1994). However, similar levels of resistance were observed over a range of inoculum levels for several viruses, including cucumber mosaic virus (CMV) (Cuozzo et al., 1988), arabis mosaic virus (Bertioli et al., 1992), potato leafroll virus (PLRV) (Kawchuk et al., 1990), and potato virus S (Mackenzie and Tremaine, 1990; MacKenzie et al., 1991). From an applied point of view, higher levels of protection would be most valuable, but perhaps the most critical factor is whether the levels of resistance are sufficient relative to inoculum concentrations likely to be encountered in the field.

The issue of inoculum concentration is particularly relevant to vector-mediated transmission. In the majority of experiments, resistance assays were performed by rub inoculation. Where it has been tested, however, CP-mediated protection also is effective against insect-vectored transmission (Table 4). In some cases, the viruses could be transmitted only by their vectors (e.g., PLRV, aphid transmitted; RSV, leafhopper transmitted; TYLCV, whitefly transmitted); thus, all tests were performed using insect-mediated transmission (Hayakawa et al., 1992; Kawchuk et al., 1990; Kunick et al., 1994; van der Wilk et al., 1991). In most experiments where comparisons were made between aphid transmission and rub inoculation, the lines that were resistant to rub inoculation also were resistant to aphid inocula- 
Table 4. Viral coat protein-mediated resistance to inoculation by natural vectors.

\begin{tabular}{|c|c|c|c|c|}
\hline \multirow[b]{2}{*}{ Virus $^{2}$} & \multirow[b]{2}{*}{ Vector } & \multicolumn{2}{|c|}{ Protection against } & \multirow[b]{2}{*}{ Reference } \\
\hline & & $\begin{array}{c}\text { Rub } \\
\text { inoculation }\end{array}$ & $\begin{array}{l}\text { Vector } \\
\text { inoculation }\end{array}$ & \\
\hline$\overline{\mathrm{RSV}}$ & Planthopper & Not tested ${ }^{y}$ & Protected & Hayakawa et al., 1992 \\
\hline PLRV & Aphid & Not tested ${ }^{y}$ & Protected & $\begin{array}{l}\text { Kawchuk et al., } 1990 \\
\text { van der Wilk et al., } 1991\end{array}$ \\
\hline TYLCV & Whitefly & Not tested ${ }^{y}$ & Protected & Kunik et al., 1994 \\
\hline CMV & Aphid & Protected & Protected & $\begin{array}{l}\text { Quemada et al., } 1991 \\
\text { Gonsalves et al., } 1992\end{array}$ \\
\hline $\begin{array}{l}\text { PVX, } \\
\text { PVY } \\
\text { TRV }\end{array}$ & $\begin{array}{l}\text { Aphid } \\
\text { Nematode }\end{array}$ & $\begin{array}{l}\text { Protected } \\
\text { Protected }\end{array}$ & $\begin{array}{l}\text { Protected } \\
\text { Not protected }\end{array}$ & $\begin{array}{l}\text { Lawson et al., } 1990 \\
\text { Ploeg et al., } 1993\end{array}$ \\
\hline
\end{tabular}

${ }^{2}$ See Table 3 for complete virus names.

${ }^{y}$ Virus is not transmitted by rub inoculation.

tion (CMV: Gonsalves et al., 1992; Quemada et al., 1991) [PVX, potato virus Y (PVY): Lawson et al., 1990]. In contrast to these insecttransmitted viruses, the $\mathrm{CP}$ of tobacco rattle virus conferred protection against rub inoculation, but not against nematode transmission (Ploeg et al., 1993). Ploeg et al. (1993) suggest that protection against nematode transmission fails because the nematodes inject more virus particles into a cell than is normally achieved by manual inoculation.

As with naturally occurring virus resistance genes, strain specificity is an important question, and different genes (be they engineered or naturally occurring) vary in their specificity. As a general rule, the plants were best protected against the virus (or strain) from which the $\mathrm{CP}$ gene was derived, but in many cases, the transgenic plants also were protected against additional virus strains, related heterologous viruses, or both. The CP gene of ZYMV-Ct conferred protection against a variety of other ZYMV strains and the closely related potyvirus WMV, but not against the less closely related papaya ringspot virus (Grumet et al., 1994). Namba et al. (1991), Nejidat and Beachy (1990), Pang et al. (1992), and van Dun and Bol (1988) observed a correlation between the extent of protection and the relatedness between the challenge virus and the virus from which the $\mathrm{CP}$ gene was derived.

There are also, however, some surprising results. The $\mathrm{CP}$ gene of the potyvirus lettuce mosaic virus (LMV) conferred complete protection against the heterologous virus PVY (66\% amino acid homology to LMV), but did not protect against tobacco etch virus, which has a similar percent amino acid homology (Dinant et al., 1993). Interestingly, Murray et al. (1993) reported that corn plants expressing the CP gene of the maize dwarf mosaic virus (MDMV) potyvirus were not only protected against MDMV, but also showed reduced symptom severity when inoculated with maize chlorotic mottle virus (MCMV), a member of the carmovirus group. In fact, when plants were inoculated with a mixture of MDMV and MCMV, they were better protected than when inoculated with MCMV alone.

In summary, CP-mediated protection has been successfully applied to a variety of plant viruses and, in many cases, related strains or viruses. Since CP-mediated protection is the strategy that has been most widely used to date, virtually all of the field trials with virusresistant transgenic plants have used $\mathrm{CP}$-expressing plants. A discussion of the field trial results will be presented in a later section.

\section{Resistance mediated by other viral genes}

Several other types of viral genes have conferred resistance, including replicase genes, movement protein genes, and protease genes (Table 5). The use of viral-encoded replicase genes appears to be promising. As for CP-mediated resistance, replicase-mediated resistance was first demonstrated with TMV (Golemboski et al., 1990). In this case, however, the resistance was inadvertent. These researchers sought to determine the function of a putative $54-\mathrm{kDa}$ protein encoded within the replicase gene and discovered that the 54$\mathrm{kDa}$-expressing transgenic plants were completely resistant to TMV infection, even at inoculum levels up to 1000 -fold higher than conferred by the TMV CP gene. Replicase-mediated protection also has been demonstrated for viruses representing four additional virus
Table 5. Genetically engineered plant virus resistance using nonstructural viral protein genes.

\begin{tabular}{|c|c|c|c|}
\hline Virus group & Virus $^{z}$ & Host species & Reference \\
\hline \multicolumn{4}{|l|}{ Replicase } \\
\hline Cucumovirus & CMV & Tobacco & Anderson et al., 1992 \\
\hline Potexvirus & PVX & Tobacco & Braun and Hemenway, 1992 \\
\hline & & Tobacco & Longstaff et al., 1993 \\
\hline Potyvirus & PVY & Tobacco & Audy et al., 1994 \\
\hline Tobamovirus & TMV & $\begin{array}{l}\text { Tobacco } \\
\text { Tobacco }\end{array}$ & $\begin{array}{l}\text { Golemboski et al., } 1990 \\
\text { Donson et al., } 1993\end{array}$ \\
\hline Tobravirus & $\mathrm{PEBV}^{\mathrm{z}}$ & $\begin{array}{l}\text { Nicotiana } \\
\text { benthamiana }\end{array}$ & MacFarlane and Davies, 1992 \\
\hline Tombusvirus & CyRSV $^{z}$ & N. benthamiana & Rubino et al., 1993 \\
\hline $\begin{array}{l}\text { Movement protein } \\
\text { Tobamovirus }\end{array}$ & & & \\
\hline Tobamovirus & TMV & Tobacco & Malyshenko et al., 1993 \\
\hline Protease & & & \\
\hline Potyvirus & PVY & Tobacco & Vardi et al., 1993 \\
\hline
\end{tabular}

${ }^{2} \mathrm{PEBV}=$ pea early browning virus, $\mathrm{CyRSV}=$ cymbidium ringspot virus. See Table 3 for complete names of other viruses.

groups: potexviruses (Braun and Hemenway, 1992; Longstaff et al., 1993), tobraviruses (MacFarlane and Davies, 1992), cucumoviruses (Anderson et al., 1992), and tombusviruses (Rubino et al., 1993). As with CP-mediated resistance, in most cases, the level of resistance varied among different transgenic lines, but, in several examples, the level of resistance observed in the most resistant replicase-expressing line was greater than that for the CP-expressing lines (Anderson et al., 1992; Braun and Hemenway, 1992; MacFarlane and Davies, 1992). To my knowledge, reports of testing replicase-expressing plants in the field have not been published.

Two newly demonstrated approaches to pathogen-derived resistance use viral movement proteins or protease genes. Cell-to-cell transport of viruses can involve a viral-encoded movement protein (MP) that interacts with the plasmodesmata to increase the macromolecular exclusion limit and facilitate viral spread to adjacent cells (Deom et al., 1992; Wolf et al., 1989). When tobacco plants were transformed with a defective MP from a TMV mutant, or with the MP from brome mosaic virus, which cannot spread through a tobacco plant, the transgenic plants were protected against infection by TMV (Malyshenko et al., 1993). Presumably, presence of the defective or nonspecies appropriate MP before viral inoculation limited the ability of the incoming functional viral MP to successfully interact with the plasmodesmata.

Another critical step in the life cycle of many viruses is proteolytic processing of viral-encoded proteins. An extreme example is the potyvirus group. The potyvirus genome codes for a single, large polyprotein that is subsequently cleaved into individual mature viral proteins through the action of three viral-encoded proteases (Dougherty and Carrington, 1988). The NIa protein, which performs the majority of cleavages, was used to transform tobacco (Vardi et al., 1993). Unexpectedly, two of 50 transgenic PVY NIa lines were resistant to PVY. In this case, the reason for resistance is unclear; the authors suggest that possible inadvertent alterations occurring during the cloning process may have resulted in a counterfunctional protein.

\section{Antisense and sense-defective RNAs}

Genetically engineered virus resistance also has been accomplished using genes that express RNA but not protein (Table 6). In these examples, antisense (the noncoding strand of RNA) and sensedefective (the coding strand with an alteration that makes it nontranslatable) viral-derived RNA sequences have been used. Presumably, interaction between complementary transgene- and viralencoded sequences interferes with translation, replication, or viral nucleic acid stability. Different types of sequences have been tested, including $3^{\prime}$ and $5^{\prime}$ noncoding regions that include viral regulatory, replication, and translation initiation sites, and coding regions of coat protein and replicase genes. In general, the RNA-mediated protection has been less effective than CP-mediated protection, as was observed for the sense and antisense ZYMV CP genes (Fang and Grumet, 1993). There are, however, notable exceptions, especially in the potyvirus and luteovirus groups where RNA-mediated protection seemed effec- 
Table 6. Genetically engineered plant virus resistance using viral-derived RNA sequences.

\begin{tabular}{|c|c|c|c|}
\hline Virus group & Virus $^{\mathrm{z}}$ & Host species & Reference \\
\hline \multicolumn{4}{|l|}{ Antisense } \\
\hline Cucumovirus & CMV & Tobacco & Cuozzo et al., 1988 \\
\hline Geminivirus & TGMV $^{\mathrm{z}}$ & Tobacco & Day et al., 1991 \\
\hline Luteovirus & PLRV & Potato & Kawchuk et al., 1991 \\
\hline Potexvirus & PVX & Tobacco & Hemenway et al., 1988 \\
\hline \multirow[t]{4}{*}{ Potyvirus } & BYMV & $\begin{array}{l}\text { Nicotiana } \\
\quad \text { benthamiana }\end{array}$ & Hammond and Kamo, 1993 \\
\hline & PVY & Tobacco & van der Vlugt et al., 1992 \\
\hline & $\mathrm{TEV}^{\mathrm{z}}$ & Tobacco & Lindbo and Dougherty, 1992a \\
\hline & ZYMV & Melon, tobacco & Fang and Grumet, 1993 \\
\hline Tobamovirus & TMV & Tobacco & Powell et al., 1989 \\
\hline Tospovirus & $\mathrm{TSWV}^{\mathrm{z}}$ & Tobacco & Pang et al., 1992 \\
\hline \multicolumn{4}{|l|}{$\begin{array}{c}\text { Sense-defective/ } \\
\text { nontranslated }\end{array}$} \\
\hline Potyvirus & TEV & Tobacco & Lindbo and Dougherty, $1992 \mathrm{~b}$ \\
\hline Tobamovirus & TMV & Tobacco & Nelson et al., 1993 \\
\hline \multirow[t]{2}{*}{ Tospovirus } & TSWV & Tobacco & de Haan et al., 1992 \\
\hline & & Tobacco & Pang et al., 1992 \\
\hline Tymovirus & TYMV & Rapeseed & Zaccomer et al., 1993 \\
\hline
\end{tabular}

${ }^{\text {zTGMV }}=$ tomato golden mosaic virus, TEV $=$ tobacco etch virus, TSWV $=$ tomato spotted wilt virus, TYMV = turnip yellow mosaic virus. See Table 3 for complete names of other viruses.

tive (Hammond and Kamo, 1993; Kawchuk et al., 1991; Lindbo and Dougherty, 1992a, 1992b). Thus, in some cases, RNA-mediated protection may prove a useful strategy for engineering resistance.

\section{Viral parasites}

Interestingly, despite their extreme simplicity and complete dependence on the host cell for all metabolic activity, several groups of viruses can acquire accompanying nucleic acid sequences that may be viewed as molecular parasites (Francki, 1985). These sequences, which include satellites and defective interfering particles (DIs), are not essential for virus function and can suppress symptom development, multiplication of the helper virus, or both (Collmer and Howell, 1992; Roosnick et al., 1992; Roux et al., 1991). As such, they have become candidate sequences for genetically engineering virus resistance. Examples to date have centered around the satellites of CMV and tobacco ringspot virus, and the DIs of African cassava mosaic virus, beet curly top virus, and cymbidium ringspot virus (Table 7; see references cited there). Transgenic plants have been engineered to express the satellite or DI sequences; upon challenge inoculation by the helper virus, the transgene-expressed sequences become amplified by the viral replication machinery. The inoculated leaves become infected in most cases, but leaves developing later are protected from severe symptom development. The degree of protection is insensitive to inoculum concentration and independent of the level of expression of transgene-derived sequences (Harrison et al., 1987; Jacquemond et al., 1988). Protection conferred by CMV satRNA was effective against

Table 7. Genetically engineered plant virus resistance using viral parasites.

\begin{tabular}{|c|c|c|c|}
\hline Virus group & Virus $^{z}$ & Host species & Reference \\
\hline \multicolumn{4}{|l|}{ Satellite } \\
\hline \multirow[t]{5}{*}{ Cucumovirus } & CMV & Tobacco & Harrison et al., 1987 \\
\hline & & Tobacco & Jaquemond et al., 1988 \\
\hline & & Tobacco & Yie et al., 1992 \\
\hline & & Tomato & Saito et al., 1992 \\
\hline & & Tomato & McGarvey et al., 1994 \\
\hline Nepovirus & TobRV $^{z}$ & Tobacco & Gerlach et al., 1987 \\
\hline \multicolumn{4}{|l|}{$\begin{array}{l}\text { Defective- } \\
\text { interfering }\end{array}$} \\
\hline \multirow[t]{2}{*}{ Geminivirus } & $\mathrm{ACMV}^{\mathrm{z}}$ & $\begin{array}{l}\text { Nicotiana } \\
\text { benthamiana }\end{array}$ & Stanley et al., 1990 \\
\hline & $\mathrm{BCTV}^{2}$ & N. benthamiana & Frischmuth and Stanley, 1994 \\
\hline Tombusvirus & CyRSV & N. benthamiana & Kollar et al., 1993 \\
\hline
\end{tabular}

${ }^{2} \mathrm{TobRV}=$ tobacco ringspot virus, ACMV = African cassava mosaic virus, $\mathrm{BCTV}=$ beet curly top virus. See Tables 3 and 5 for complete names of other viruses. aphid transmission as well as rub inoculation (Jacquemond et al., 1988). After inoculation, the amplified transgene-derived sequences become encapsidated in the helper virus $\mathrm{CP}$ and are transmitted in subsequent passages along with the helper virus (Gerlach et al., 1987; Harrison et al., 1987; Stanley et al., 1990). Although only a limited number of viruses have satellites or DIs, this approach, where available, seems effective. Other researchers are investigating the possibility of creating artificial DIs for viruses that do not have them naturally (e.g., Huntley and Hall, 1993; Marsh et al., 1991). However, because satellites and DIs are replicating entities with a complex biology, several concerns exist about the ecological safety of this approach (e.g., Tepfer, 1993). These concerns have detracted from testing satellite- or DI-expressing plants in the field.

\section{FIELD PERFORMANCE}

Ultimately, if we are to use these strategies to develop virusresistant cultivars, the materials must perform well in the field not only with regard to general crop growth and yield, but also in response to virus infection. A frequently asked question is what effects do regeneration, transformation, and expression of the viral gene per se have on crop performance? In respect to regeneration and transformation, plants possibly might be affected by somaclonal variation or by the site of integration of the transgenes. As might be expected, in a study comparing field performance of various potato lines, those derived from regenerated or transgenic plants were more variable than those from tuber nodal shoot cuttings (Dale and McPartlan, 1992). In a study comparing field performance of transgenic potato lines expressing PVX CP with their nontransgenic counterparts, the degree of variation was genotype dependent (Hoekema et al., 1989; Jongedijk et al., 1992). Even though somaclonal variation occurred, several lines were obtained that retained their agronomic or horticultural qualities. Clearly, there are possible effects of the transformation and regeneration processes that should be screened for during early testing.

Another concern is the effect of viral gene expression. With the exception of examples of the introduction of $\mathrm{CP}$ genes from necrosisinducing TMV or tomato mosaic virus (ToMV) strains into hypersensitive Nicotiana genotypes (Culver and Dawson, 1991; Pfitzner and Pfitzner, 1992), transgenic plants expressing viral sequences have appeared phenotypically normal. The sequences per se, even those of satellites or DIs, did not cause any symptom development. In experiments comparing the yield of noninoculated transgenic and control plants, there was no difference between transgenic TMV CP-expressing tomato plants, or between PVX CP- and PVY CP-expressing potato plants, and their respective nontransgenic controls (Kaniewski et al., 1990; Sanders et al., 1992). Thus, CP gene(s) did not appear to have a negative effect.

The majority of experiments testing virus resistance in the field have been performed by industry personnel; they requested $\approx 75 \%$ of the U.S. Dept. of Agriculture permits issued from 1987 to 1993 for transgenic plants expressing viral genes. Although only a few field trial studies have been published, those that have, have been encouraging. The percentage of infection for transgenic tomato plants expressing TMV or ToMV CP genes was significantly lower than for nontransgenic controls (Nelson et al., 1988; Sanders et al., 1992). In two trials, the inoculated control plants exhibited yield losses of $35 \%$ and $69 \%$, while yield of the inoculated transgenic plants was not reduced. Similarly, the yield of a control potato line infected with PVX and PVY was reduced by $28 \%$, while a transgenic potato line expressing PVX and PVY CP genes was free of symptoms and did not suffer yield loss (Kaniewski et al., 1990). Jongedijk et al. (1992) observed that PVX CP-expressing potato plants had fewer infected seed tubers. In an experiment with natural aphid-mediated spread of CMV, transgenic CMV CP-expressing cucumber plants had significantly less viral infection relative to nontransgenic, susceptible controls (Gonsalves et al., 1992).

Another question that is asked frequently regarding engineered virus resistance concerns the long-term stability of this approach. This is potentially an important issue for both naturally occurring and engineered resistance genes. Virus evolution can, and has, resulted in strains that can overcome host-derived resistance genes (Fraser, 1990); 
this is likely to be the case for engineered resistance as well. Although the occurrence of specific strains overcoming CP-mediated resistance has not been reported yet, it is too soon to draw any conclusions. All trials to date have been in experimental plots; we do not currently have the large-scale agricultural plantings that will ultimately test the usefulness and longevity of the genes. There is an interesting example, however, of a mutant strain of pea early browning virus that arose in laboratory tests and was able to overcome replicase-mediated protection (MacFarlane and Davies, 1992). In my opinion, however, the possibility of viral strains that are capable of overcoming resistance should not preclude the development of these types of resistance strategies. We should, however, view these genetically engineered resistance genes as potential components of a broader-based program to develop virus-resistant cultivars.

In summary, substantial progress has been made in the past decade toward genetically engineering virus-resistant crops. As more genes, viruses, and hosts are used, we should see increasing numbers of horticultural crops that have been engineered for virus resistance.

\section{Literature Cited}

Anderson, J.M., P. Palukaitis, and M. Zaitlin. 1992. A defective replicase gene induces resistance to cucumber mosaic virus in transgenic tobacco plants. Proc. Natl. Acad. Sci. USA 89:8759-8763.

Audy, P., P. Palukaitis, S.A. Slack, and M. Zaitlin. 1994. Replicase-mediated resistance to potato virus $\mathrm{Y}$ in transgenic tobacco plants. Mol. PlantMicrobe Interact. 7:15-22.

Barker, H., B. Reavy, A. Kumar, K.D. Webster, and M.A. Mayo. 1992. Restricted virus multiplication in potatoes transformed with the coat protein gene of potato leafroll luteovirus: Similarities with a type of host gene-mediated resistance. Ann. Appl. Biol. 120:55-64.

Beachy, R.N., S. Loesch-Fries, and N.E. Tumer. 1990. Coat protein-mediated resistance against virus infection. Annu. Rev. Phytopathol. 28:451-474.

Bertioli, D.J., J.I. Cooper, M.L. Edwards, and W.S. Hawes. 1992. Arabis mosaic nepovirus coat protein in transgenic tobacco lessens disease severity and virus replication. Ann. Appl. Biol. 120:47-54.

Brault, V., T. Candresse, O. le Gall, R.P. Delbos, M. Lanneau, and J. Dunez. 1993. Genetically engineered resistance against grapevine chrome mosaic nepovirus. Plant Mol. Biol. 21:89-97.

Braun, C.J. and C.L. Hemenway. 1992. Expression of amino-terminal portions or full-length viral replicase genes in transgenic plants confers resistance to potato virus X infection. Plant Cell 4:735-744.

Chia, T.F., Y.S. Chan, and N.H. Chua. 1992. Characterization of cymbidium mosaic virus coat protein gene and its expression in transgenic tobacco plants. Plant Mol. Biol. 18:1091-1099.

Collmer, C.W. and S.H. Howell. 1992. Role of satellite RNA in the expression of symptoms caused by plant viruses. Annu. Rev. Phytopathol. 30:419442.

Culver, J.N. and W.O. Dawson. 1991. Tobacco mosaic virus elicitor coat protein genes produce a hypersensitive phenotype in transgenic Nicotiana sylvestris plants. Mol. Plant-Microbe Interact. 5:458-463.

Cuozzo, M., K.M. O'Connell, W. Kaniewski, R.-X. Fang, N.-H. Chua, and N.E. Tumer. 1988. Viral protection in transgenic tobacco plants expressing the cucumber mosaic virus coat protein or its antisense RNA. Bio/Technology 6:549-557.

Dale, P.J. and H.C. McPartlan. 1992. Field performance of transgenic potato plants compared with controls regenerated from tuber discs and shoot cuttings. Theor. Appl. Genet. 84:585-591.

Day, A.G., E.R. Bejarano, K.W. Buck, M. Burrell, and C.P. Lichtenstein. 1991. Expression of an antisense viral gene in transgenic tobacco confers resistance to the DNA virus tomato golden mosaic virus. Proc. Natl. Acad. Sci. USA 88:6721-6725.

de Haan, P., J.J.L. Gielen, M. Prins, I.G. Wijkamp, A. van Schepen, D. Peters, M.Q.J.M. van Grinsven, and R. Goldbach. 1992. Characterization of RNAmediated resistance to tomato spotted wilt virus in transgenic tobacco plants. Bio/Technology 10:1133-1138.

Deom, C.M., M. Lapidot, and R.N. Beachy. 1992. Plant virus movement proteins. Cell 69:221-224.

Dinant, S., F. Blaise, C. Kusiak, S. Astier-Manifacier, and J. Albouy. 1993. Heterologous resistance to potato virus $\mathrm{Y}$ in transgenic tobacco plants expressing the coat protein gene of lettuce mosaic potyvirus. Phytopathology 83:818-824.

Donson, J., C.M. Kearny, T.H. Turpen, I.A. Khan, G. Kurath, A.M. Turpen, G.E. Jones, W.O. Dawson, and D.J. Lewandowski. 1993. Broad resistance to tobamoviruses is mediated by a modified tobacco mosaic virus replicase transgene. Mol. Plant-Microbe Interact. 6:635-642.

Dougherty, W.G. and J.C. Carrington. 1988. Expression and function of potyviral gene products. Annu. Rev. Phytopathol. 26:123-143

Fang, G. and R. Grumet. 1993. Genetic engineering of potyvirus resistance using constructs derived from the zucchini yellow mosaic virus coat protein gene. Mol. Plant-Microbe Interact. 6:358-367.

Fitch, M.M.M., R.M. Manshardt, D. Gonsalves, J.L. Slightom, and J.C. Sanford. 1992. Virus resistant papaya plants derived from tissues bombarded with the coat protein gene of papaya ringspot virus. Bio/Technology 10:1466-1472.

Fitchen, J.H. and R.N. Beachy. 1993. Genetically engineered protection against viruses in transgenic plants. Annu. Rev. Microbiol. 47:739-763.

Francki, R.I.B. 1985. Plant virus satellites. Annu. Rev. Microbiol. 39:151-174.

Fraser, R.S.S. 1990. The genetics of resistance to plant viruses. Annu. Rev. Phytopathol. 28:179-200.

Frischmuth, T. and J. Stanley. 1994. Beet curly top virus symptom amelioration in Nicotiana benthamiana transformed with a naturally occurring viral subgenomic DNA. Virology 200:826-830.

Gadani,F., L.M. Mansky, R. Medici, W.A. Miller, and J.H. Hull. 1990. Genetic engineering of plants for virus resistance. Arch. Virol. 115:1-21.

Gasser, C.S. and R.T. Fraley. 1989. Genetically engineering of plants for crop improvement. Science 244:1293-1299.

Gerlach, W.L., D. Llewellyn, and J. Haseloff. 1987. Construction of a plant disease resistance gene from the satellite RNA of tobacco ringspot virus. Nature 328:802-805.

Gielen, J.J.L., P. de Haan, A.J. Kool, D. Peters, M.Q.J.M. van Grinsven, and R.W. Goldbach. 1991. Engineered resistance to tomato spotted wilt virus, a negative-strand RNA virus. Bio/Technology 9:1363-1367.

Golemboski, D.B., G.P. Lomonossoff, and M. Zaitlin. 1990. Plants transformed with a tobacco mosaic virus nonstructural gene sequence are resistant to the virus. Proc. Natl. Acad. Sci. USA 87:6311-6315.

Gonsalves, C., B. Xue, M. Yepes, M. Fuchs, K. Ling, S. Namba, P. Chee, J.L. Slightom, and D. Gonsalves. 1994. Transferring cucumber mosaic viruswhite leaf strain coat protein gene into Cucumis melo L. and evaluating transgenic plants for protection against infection. J. Amer. Soc. Hort. Sci. 119:345-355.

Gonsalves, D., P. Chee, R. Provvidenti, R. Seem, and J.L. Slightom. 1992. Comparison of coat protein-mediated and genetically-derived resistance in cucumbers to infection by cucumber mosaic virus under field conditions with natural challenge inoculations by vectors. Bio/Technology 10:15621570 .

Grumet, R. 1990. Genetically engineered plant virus resistance. HortScience 25:508-513.

Grumet, R. 1994. Development of virus resistant plants via genetic engineering. Plant Breeding Rev. 12:47-79.

Grumet, R., R.C. Yadav, G. Akula, S. Hammar, and R. Provvidenti. 1995. Genetic engineering of virus resistance in cucurbit crops. Proc. Cucurbitaceae '94. (In press.)

Hammond, J. and K.K. Kamo. 1993. Transgenic coat protein and antisense RNA resistance to bean yellow mosaic potyvirus. Acta Hort. 336:171-178.

Harrison, B.D., M.A. Mayo, and D.C. Baulcombe. 1987. Virus resistance in transgenic plants that express cucumber mosaic virus satellite RNA. Nature (London) 328:799-802.

Hayakawa, T., Y. Zhu, K. Itoh, Y. Kimura, T. Izawa, K. Shimamoto, and S. Toriyama. 1992. Genetically engineered rice resistant to rice stripe virus, an insect-transmitted virus. Proc. Natl. Acad. Sci. USA 89:9865-9869.

Hemenway, C., R.-X. Fang, W.K. Kaniewski, N.-H. Chua, and N.E. Tumer. 1988. Analysis of the mechanism of protection in transgenic plants expressing the potato virus $X$ coat protein or its antisense RNA. EMBO J. 7:12731280 .

Hill, K.K., N. Jarvis-Eagan, E.L. Halk, K.J. Krahn, L.W.Liao, R.S. Mathewson, D.J. Merlo, S.E. Nelson, K.E. Rashka, and L.S. Loesch-Fries. 1991. The development of virus-resistant alfalfa, Medicago sativa $\mathrm{L}$. Bio/Technology 9:373-377.

Hoekema, A., M.J. Huisman, L. Molendijk, P.J.M. van den Elzen, and B.J.C. Cornelissen. 1989. The genetic engineering of two commercial potato cultivars for resistance to potato virus X. Bio/Technology 7:273-278.

Hull, R. and J.W. Davies. 1992. Approaches to nonconventional control of plant virus diseases. Crit. Rev. Plant Sci. 11:17-33.

Huntley, C.C. and T.C. Hall. 1993. Minus sense transcripts of brome mosaic virus RNA-3 intercistronic region interfere with viral replication. Virology 192:290-297.

Jacquemond, L., J. Amselem, and M. Tepfer. 1988. Gene coding for a monomeric form of cucumber mosaic virus satellite RNA confers tolerance to CMV. Mol. Plant-Microbe Interact. 1:311-316.

Jongedijk, E., A.A.J.M. de Schutter, T. Stolte, P.J.M. van den Elzen, and B.J.C. Cornelissen. 1992. Increased resistance to potato virus $\mathrm{X}$ and preservation of cultivar properties in transgenic potato under field conditions. Bio/ Technology 10:422-429.

Kaniewski, W., C. Lawson, B. Sammons, L. Haley, J. Hart, X. Delannay, and N.E. Tumer. 1990. Field resistance of transgenic Russet Burbank potato to 
effects of infection by potato virus $\mathrm{X}$ and potato virus $\mathrm{Y}$. Bio/Technology 8:750-754.

Kawchuk, L.M., R.R. Martin, and J. McPherson. 1990. Resistance in transgenic potato expressing the potato leafroll virus coat protein gene. Mol. PlantMicrobe Interact. 3:301-307.

Kawchuk, L.M., R.R. Martin, and J. McPherson. 1991. Sense and antisense RNA-mediated resistance to potato leafroll virus in Russet Burbank potato plants. Mol. Plant-Microbe Interact. 4:247-253.

Kollar, A., T. Dalmay, and J. Burgyan. 1993. Defective interfering RNAmediated resistance against cymbidium ringspot virus in transgenic plants. Virology 193:313-318.

Knott, D.R. and J. Dvorak. 1976. Alien germplasm as a source of resistance to disease. Annu. Rev. Phytopathol. 14:211-235.

Kunik, T., R. Salomon, D. Zamir, N. Navot, M. Zeidan, I. Michelson, Y. Gafni, and H. Czosnek. 1994. Transgenic tomato plants expressing the tomato yellow leaf curl virus capsid protein are resistant to the virus. Bio/ Technology 12:500-504.

Kyle, M.M. 1993. Resistance to viral diseases of vegetables: Genetics and breeding. Timber Press, Portland, Ore.

Lawson, C., W. Kaniewski, L. Haley, R. Rozman, C. Newell, P. Sanders, and N.E. Tumer. 1990. Engineering resistance to mixed virus infection in a commercial potato cultivar: Resistance to potato virus $\mathrm{X}$ and potato virus $\mathrm{Y}$ in transgenic Russet Burbank. Bio/Technology 8:127-134.

Lindbo, J.A. and W.G. Dougherty. 1992a. Pathogen-derived resistance to a potyvirus: Immune and resistant phenotypes in transgenic tobacco expressing altered forms of a potyvirus coat protein nucleotide sequence. Mol. Plant-Microbe Interact. 5:144-153.

Lindbo, J.A. and W.G. Dougherty. 1992b. Untranslatable transcripts of the tobacco etch virus coat protein gene sequence can interfere with tobacco etch virus replication in transgenic plants and protoplasts. Virology 189:725733.

Ling, K., S. Namba, C. Gonsalves, J.L. Slightom, and D. Gonsalves. 1991. Protection against detrimental effects of potyvirus infection in transgenic tobacco plants expressing the papaya ringspot virus coat protein gene. Bio/ Technology 9:752-758.

Loesch-Fries, L.S., D. Merlo, T. Zinnen, L. Burhop, K. Hill, K. Krahn, N. Jarvis, S. Nelson, and E. Halk. 1987. Expression of alfalfa mosaic virus RNA 4 in transgenic plants confers virus resistance. EMBO J. 6:18451851.

Longstaff, M., G. Brigneti, F. Boccard, S. Chapman, and D. Baulcombe. 1993. Extreme resistance to potato virus $\mathrm{X}$ infection in plants expressing a modified component of the putative viral replicase. EMBO J. 12:379-386.

MacFarlane, S.A. and J.W. Davies. 1992. Plants transformed with a region of the 201-kilodalton replicase gene from pea early browning virus RNA1 are resistant to virus infection. Proc. Natl. Acad. Sci. USA 89:5829-5833.

MacKenzie, D.J. and P.J. Ellis. 1992. Resistance to tomato spotted wilt virus infection in transgenic tobacco expressing the viral nucleocapsid gene. Mol. Plant-Microbe Interact. 5:34-40.

MacKenzie, D.J. and J.H. Tremaine. 1990. Transgenic Nicotiana debneyii expressing viral coat protein are resistant to potato virus $\mathrm{S}$ infection. J. Gen. Virol. 71:2167-2170

MacKenzie, D.J., J.H. Tremaine, and J. McPherson. 1991. Genetically engineered resistance to potato virus $\mathrm{S}$ in potato cultivar Russet Burbank. Mol. Plant-Microbe Interact. 4:95-102.

Malyshenko, S.I., O.A. Kondakova, J.V.Nazarova, I.B. Kaplan, M.E. Taliansky, and J.G. Atabekov. 1993. Reduction of tobacco mosaic virus accumulation in transgenic plants producing non-functional viral transport proteins. J. Gen. Virol. 74:1149-1156.

Marsh, L.E., G.P. Pogue, J.P. Connell, and T.C. Hall. 1991. Artificial defective interfering RNAs derived from brome mosaic virus. J. Gen. Virol. 72:17871792.

McGarvey, P.B., M.S. Montasser, and J.M. Kaper. 1994. Transgenic tomato plants expressing satRNA are tolerant to some strains of cucumber mosaic virus. J. Amer. Soc. Hort. Sci. 119:642-647.

Murray, L.E., L.G. Elliott, S.A. Capitant, J.A. West, K.K. Hanson, L. Scarafia, S. Johnston, C. DeLuca-Flaherty, S. Nichols, D. Cunanan, P.S. Dietrich, I.J. Mettler, S. Dewald, D.A. Warnick, C. Rhodes, R.M. Sinibaldi, and K.J. Brunke. 1993. Transgenic corn plants expressing MDMV strain B coat protein are resistant to infections of maize dwarf mosaic virus and maize chlorotic mottle virus. Bio/Technology 11:1559-1564.

Nakajima, M., T. Hayakawa, I. Nakamura, and M. Suzuki. 1993. Protection against cucumber mosaic virus (CMV) strains $\mathrm{O}$ and $\mathrm{Y}$ and chrysanthemum mild mottle virus in transgenic tobacco plants expressing CMV-O coat protein. J. Gen. Virol. 74:319-322.

Namba, S., K. Ling, C. Gonsalves, D. Gonsalves, and J.L. Slightom. 1991. Expression of the gene encoding the coat protein of cucumber mosaic virus (CMV) strain WL appears to provide protection to tobacco plants against infection by several different CMV strains. Gene 107:181-188.

Namba, S., K. Ling, C. Gonsalves, J.L. Slightom, and D. Gonsalves. 1992.
Protection of transgenic plants expressing the coat protein gene of watermelon mosaic virus II or zucchini yellow mosaic virus against six potyviruses. Phytopathology 82:940-946.

Nejidat, A. and R.N. Beachy. 1989. Decreased levels of TMV coat protein in transgenic tobacco plants at elevated temperatures reduce resistance to TMV infection. Virology 173:531-538.

Nejidat, A. and R.N. Beachy. 1990. Transgenic tobacco plants expressing a coat protein gene of tobacco mosaic virus are resistant to some other tobamoviruses. Mol. Plant-Microbe Interact. 3:247-251.

Nelson, A., D.A. Roth, and J.D. Johnson. 1993. Tobacco mosaic virus infection of transgenic Nicotiana tabacum plants is inhibited by antisense constructs directed at the 5' region of viral RNA. Gene 127:227-232.

Nelson, R.S., S.M. McCormick, X. Delaney, P. Dube, J. Layton, E.J. Anderson, M. Kaniewski, R.K. Proksch, R.B. Horsch, S.G. Rogers, R.T. Fraley, and R.N. Beachy. 1988. Virus tolerance, plant growth, and field performance of transgenic tomato plants expressing coat protein from tobacco mosaic virus. Bio/Technology 6:403-409.

Nelson, R.S., P. Powell, and R.N. Beachy. 1990. Coat protein-mediated protection against virus infection, p. 13-24. In: G.W. Lycett and D. Grierson (eds.). Genetic engineering of crop plants. Butterworths, Borough Green, Sevenoaks, Kent, U.K

Pang, S.-Z., P. Nagpala, M. Wang, J.L. Slightom, and D. Gonsalves. 1992. Resistance to heterologous isolates of tomato spotted wilt virus in transgenic tobacco expressing its nucleocapsid protein gene. Phytopathology 82:1223 1229.

Pfitzner, U.M. and A.J.P. Pfitzner. 1992. Expression of a viral avirulence gene in transgenic plants is sufficient to induce the hypersensitive defense reaction. Mol. Plant-Microbe Interact. 5:318-321.

Ploeg, A.T., A. Mathis, J.F. Bol, D.J.F. Brown, and D.J. Robinson. 1993. Susceptibility of transgenic tobacco plants expressing tobacco rattle virus coat protein to nematode-transmitted and mechanically inoculated tobacco rattle virus. J. Gen. Virol. 74:2709-2715.

Powell, P.A., D.M. Stark, P.R. Sanders, and R.N. Beachy. 1989. Protection against tobacco mosaic virus in transgenic plants that express tobacco mosaic virus antisense RNA. Proc. Natl. Acad. Sci. USA 86:6949-6952.

Powell-Abel, P., R.S. Nelson, B. De, N. Hoffmann, S.G. Rogers, R.T. Fraley, and R.N. Beachy. 1986. Delay of disease development in transgenic plants that express the tobacco mosaic virus coat protein gene. Science 232:738743.

Quemada, H.D., D. Gonsalves, and J.L. Slightom. 1991. Expression of coat protein gene from cucumber mosaic virus strain $\mathrm{C}$ in tobacco: Protection against infection by CMV strain transmitted mechanically or by aphids. Phytopathology 81:794-802.

Regner, F., A. da Camara Machado, M.L. da Camara Machado, H. Steinkellner, D. Mattanovich, V. Hanzer, H. Weiss, and H. Katinger. 1992. Coat protein mediated resistance to plum pox virus in Nicotiana clevelandii and $N$. benthamiana. Plant Cell Rpt. 11:30-33.

Roossinck, M.J., D. Sleat, and P. Palukaitis. 1992. Satellite RNAs of plant viruses: Structures and biological effects. Microbiol. Rev. 56:265-279.

Roux, L., A.E. Simon, and J.J. Holland. 1991. Effects of defective interfering viruses on virus replication and pathogenesis in vitro and in vivo. Adv. Virus Res. 40:181-211.

Rubino, L., R. Lupo, and M. Russo. 1993. Resistance to cymbidium ringspot tombusvirus infection in transgenic Nicotiana benthamiana plants expressing a full-length viral replicase gene. Mol. Plant-Microbe Interact. 6:729734.

Saito, Y., T. Komari, C. Masuta, Y. Hayashi, T. Kumashiro, and Y. Takanami. 1992. Cucumber mosaic virus-tolerant transgenic tomato plants expressing a satellite RNA. Theor. Appl. Genet. 83:679-683.

Sanders, P.R., B. Sammons, W. Kaniewski, L. Haley, J. Layton, B.J. LaVallee, X. Delannay, and N.E. Tumer. 1992. Field resistance of transgenic tomatoes expressing the tobacco mosaic virus or tomato mosaic virus coat protein genes. Phytopathology 82:683-690.

Sanford, J.C. and S.A. Johnston. 1985. The concept of parasite derived resistance-Deriving resistance genes from the parasite's own genome. J. Theor. Biol. 113:395-405.

Scholthof, K-B.G., H.B. Scholthof, and A.O. Jackson. 1993. Control of plant virus diseases by pathogen-derived resistance in transgenic plants. Plant Physiol. 102:7-12

Stanley, J., T. Frischmuth, and S. Ellwood. 1990. Defective DNA ameliorates symptoms of geminivirus infection in transgenic plants. Proc. Natl. Acad. Sci. USA 87:6291-6295.

Stark, D.M. and R.N. Beachy. 1989. Protection against potyvirus infection in transgenic plants: Evidence for broad spectrum resistance. Bio/Technology 7:1257-1262.

Tavladoraki, P., E. Benvenuto, S. Trinca, D. De Martinis, A. Cattaneo, and P. Galeffi. 1993. Transgenic plants expressing a functional single-chain antibody are specifically protected from virus attack. Nature (London) 366:469-472. 
Tepfer, M. 1993. Viral genes and transgenic plants. What are potential environmental risks? Bio/Technology 11:1125-1132.

Truve, E., A. Aaspollu, J. Honkanen, R. Puska, M. Mehto, A. Hassi, T.H. Teeri, M. Kelve, P. Seppanen, and M. Saarma. 1993. Transgenic potato plants expressing mammalian 2'-5' oligoadenylate synthetase are protected from potato virus X infection under field conditions. Bio/Technology 11:10481051.

Tumer, N.E., K.M. O'Connell, R.S. Nelson, P.R. Sanders, R.N. Beachy, R.T. Fraley, and D.M. Shah. 1987. Expression of alfalfa mosaic virus coat protein gene confers cross-protection in transgenic tobacco and tomato plants. EMBO J. 6:1181-1188.

van der Vlugt, R.A.A., R.K. Ruiter, and R. Goldbach. 1992. Evidence for sense RNA-mediated protection to PVY ${ }^{\mathrm{N}}$ in tobacco plants transformed with the viral coat protein cistron. Plant Mol. Biol. 20:631-639.

van der Wilk, F., D.P.-L. Willink, M.J. Huisman, H. Huttinga, and R. Goldbach. 1991. Expression of the potato leafroll luteovirus coat protein gene in transgenic potato plants inhibits viral infection. Plant Mol. Biol. 17:431439.

van Dun, C.M.P. and J.F. Bol. 1988. Transgenic tobacco plants accumulating tobacco rattle virus coat protein resist infection with tobacco rattle virus and pea early browning virus. Virology 167:649-652.

van Dun, C.M.P., J.F. Bol, and L. Van Vloten-Doting. 1987. Expression of alfalfa mosaic virus and tobacco rattle virus coat protein genes in transgenic tobacco plants. Virology 159:299-305. van Dun, C.M.P., B. Overduin, L. Van Vloten-Doting, and J.F. Bol. 1988. Transgenic tobacco expressing tobacco streak virus or mutated alfalfa mosaic virus coat protein does not cross protect against alfalfa mosaic virus infection. Virology 164:383-389.

Vardi, E., I. Sela, O. Edelbaum, O. Livneh, L. Kuzentsova, and Y. Stram. 1993. Plants transformed with a cistron of a potato virus Y protease (NIa) are resistant to virus infection. Proc. Natl. Acad. Sci. USA 90:7513-7517.

Wenzel, G. 1985. Strategies in unconventional breeding for disease resistance. Annu. Rev. Phytopathol. 23:149-172.

Wilson, T.M.A. 1993. Strategies to protect crop plants against viruses. Proc. Natl. Acad. Sci. USA 90:3134-3141.

Wolf, S., C.M. Deom, R.N. Beachy, and W.L. Lucas. 1989. Movement protein of tobacco mosaic virus modifies plasmodesmatal size exclusion limit. Science 246:337-339.

Yie, Y., F. Zhao, S.Z. Zhao, Y.Z. Liu, Y.L. Liu, and P. Tien. 1992. High resistance to cucumber mosaic virus conferred by satellite RNA and coat protein in transgenic commercial tobacco cultivar G-140. Mol. PlantMicrobe Interact. 5:460-465.

Zaccomer, B., F. Cellier, J.C. Boyer, A.L. Haenni, and M. Tepfer. 1993. Transgenic plants that express genes including the 3' untranslated region of the turnip yellow mosaic virus (TYMV) genome are partially protected against TYMV infection. Gene 136:87-94.

Zaitlin, M. and R. Hull. 1987. Plant virus-host interactions. Annu. Rev. Plant Physiol. 38:291-315.

\title{
Novel Approaches for Genetic Resistance to Bacterial Pathogens in Flower Crops
}

\author{
Adelheid R. Kuehnle, Fure-Chyi Chen', and Nellie Sugii \\ Department of Horticulture, University of Hawaii, Honolulu, HI 96822
}

Bacterial diseases plague many flower crops. Fortunately, for ornamentals cultivated under glasshouse conditions, bacterial diseases are less prevalent than fungal or viral diseases (Dons et al., 1991). Nevertheless, bacterial diseases can be devastating when an outbreak occurs. The most common causal organisms are from five genera of bacteria: Erwinia, Xanthomonas, Pseudomonas, Clavibacter (Cornybacterium), and Agrobacterium. These bacteria cause the familiar symptoms of leaf spots, blights, rots, wilts, cankers, and galls (Powell and Lindquist, 1992) and affect many of the major cut-flower and flowering potted-plant crops (Table 1). Perhaps one of the best known bacterial diseases among ornamentals is xanthomonas bacterial blight/wilt in geranium. Despite disease control advances made since the 1960 s, before which the geranium market was virtually nonexistent due to the prevalence of bacterial blight/wilt, the disease continues to be a risk for geranium propagators and growers alike (Whealey, 1994). Forced dumping of geranium stock plants due to an outbreak of Xanthomonas even occurred this past year.

Through use of horticultural methods that practice sanitation (Baker, 1957) and pathogen exclusion, bacterial disease problems can be minimized. Sanitation is useless, however, if diseased plants are not first eliminated from the farm. Unfortunately, some growers are still reluctant to do this. Today, culture-indexed cuttings for many cutflower and potted florist crops can be obtained from specialist propagators. Limited chemical controls, such as antibiotics or copper sprays, also can be used on the farm. However, frequent usage results in pathogen resistance (Cooksey, 1990). Moreover, these controls are not curative, and they do not economically solve extensive bacterial disease problems.

\footnotetext{
Received for publication 20 Oct. 1994. Accepted for publication 16 Nov. 1994 Journal Series no. 4007 of the Hawaii Institute of Tropical Agriculture and Human Resources. Research supported in part by the State of Hawaii Governor's Agricultural Coordinating Committee Grant 89-22 and the Hawaiian Anthurium Industry Association. We thank J. Jaynes, A. Alvarez, D. Norman, and D. Coyne for their contributions. The cost of publishing this paper was defrayed in part by the payment of page charges. Under postal regulations, this paper therefore must be hereby marked advertisement solely to indicate this fact.

${ }^{1}$ Former Graduate Research Assistant of A.R. Kuehnle. Current address: National Pingtung Polytechnic Institute, Pingtung 91207, Taiwan.
}

Genetic resistance offers one way to manage disease. When combined with the use of culture-indexed propagules and sanitation, it can be a powerful control. Classical breeding offers some genetic solutions, but little has been published regarding resistance to bacterial diseases of florist crops. This dearth contrasts sharply with the active resistance breeding for other horticultural and agronomic crops and with the progress made in fungal disease resistance in some flowers crops, e.g., Fusarium spp. in carnation and tulip, Puccinia horiana Henn. (white rust) in chrysanthemum, and Colletotrichum gloeosporioides Penz. (anthracnose) in anthurium (Aragaki et al., 1968; Sparnaaij, 1991). Introgression of resistance genes, either through tissue culture manipulations, use of molecular genetics, or by genetic engineering, are supplementary breeding approaches that appear promising. Yet, despite the current and predicted importance of the floriculture industry to U.S. agriculture (1993 wholesale value approached \$3 billion), little use of novel breeding strategies for (bacterial) disease control is evident in either the public or private sector.

In the last several years, numerous papers describing genetic transformation systems for floricultural crops have appeared (Robinson and Firoozabady, 1993). Preceding and during this same period, numerous biological compounds have been identified with potent antimicrobial properties - research driven in part by the biomedical and food science fields. The objective of this paper is to discuss previous and current research that uses novel genetic strategies to control bacterial disease in various cropping systems, with focus on integrating genetic engineering with nonplant resistance genes. A case study for controlling Xanthomonas spp., species of which severely limit geranium and anthurium production, is given for anthurium, using genes derived from those of the Cecropia moth.

\section{Novel approaches: Cloning resistance genes from plants via molecular genetics}

Screening plant extracts for antibacterial activity has identified many potentially useful compounds, but it has seldom led to identification of the associated plant genes. Focusing on plant molecular signals active during early stages of infection has been more successful; many research groups are targeting host genes involved in patho- 